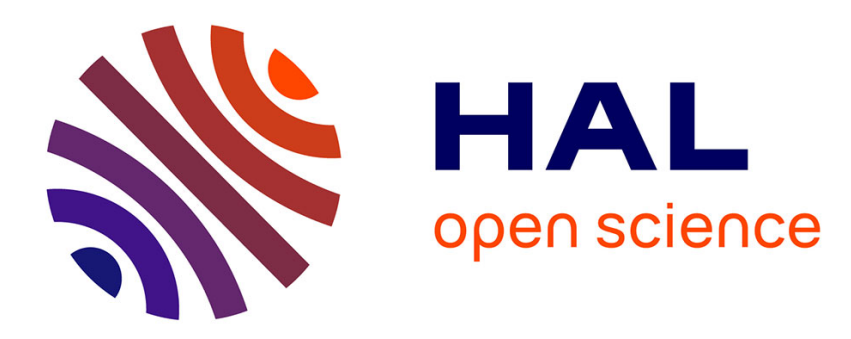

\title{
The European Community commercial policy
}

Patrick Messerlin

\section{To cite this version:}

Patrick Messerlin. The European Community commercial policy. 2010. hal-00972936

\section{HAL Id: hal-00972936 \\ https: / hal-sciencespo.archives-ouvertes.fr/hal-00972936}

Preprint submitted on 3 Apr 2014

HAL is a multi-disciplinary open access archive for the deposit and dissemination of scientific research documents, whether they are published or not. The documents may come from teaching and research institutions in France or abroad, or from public or private research centers.
L'archive ouverte pluridisciplinaire HAL, est destinée au dépôt et à la diffusion de documents scientifiques de niveau recherche, publiés ou non, émanant des établissements d'enseignement et de recherche français ou étrangers, des laboratoires publics ou privés. 


\section{The European Community commercial policy ${ }^{1}$ Patrick A. Messerlin ${ }^{2}$ \\ Final version}

\section{Introduction}

The European Community (the correct legal term in trade matters, hereafter EC) is still a recent and ongoing process. Fifty years is a short time span for such an endeavour (Annex I lists the 17 Treaties that have formed its legal basis). ${ }^{3}$ It is strictly an economic process because a straight forward political unification of Europe was out of reach, then, now, and for the decades to come. This ambiguous relation between economics and politics explains why the EC commercial policy often received the status of a foreign policy instrument. This was the case in the EC relation with former colonies (during the 1960s), developing countries (the 1970s), the Central European countries formerly in the Soviet sphere (the 1990s), and neighbours or emerging economies (the 2000s).

Yet, economic analysis shows that the trade policy of a country reflects domestic conflicts between consumers, import-competing producers, and exporters of the country more than its international relation. Hence, this paper begins (section 1) by examining the EC domestic scene - the balance between "the EC and its Member States", the sacrosanct expression used in the trade treaties signed by the EC. The development of the EC commercial policy can be seen through the tensions between the Treaty, the European Court of Justice, the Commission, and the EC Member States (hereafter ECMS).

Subsequent sections describe briefly the level of protection of the EC in the early 2000 s, before examining the EC approach to the Doha Round of the WTO during the last decade, and the possible return to trade preferences most recently. A final section concludes.

\footnotetext{
${ }^{1}$ Forthcoming in Kreinin, M.E. and M. Plummer, Editors. Handbook on International Commercial Policy. Oxford University Press.

${ }^{2}$ Professor of economics and Director of Groupe d'Economie Mondiale (GEM) at Sciences Po, Paris

${ }^{3}$ For simplicity sake, the paper uses the generic term of the "Treaty" as often as possible. Unfortunately, the drafters of the successive Treaties keep changing the numbering of the Articles. This note specifies the Treaty quoted ( $\mathrm{R}$ for the initial Treaty of Rome, F for the most recent "Functioning" or "Lisbon" Treaty).
} 


\section{Section 1. The Treaty, the Court, and the practices}

The Treaty of Rome confers upon the Community as such (not the Commission) power to conduct commercial policy. This so-called principle of the Community's "exclusive competence" makes the ECMS' Council as the decision-maker giving to the Commission a mandate to act on its behalf, with the final decision remaining in the Council's hands. ${ }^{4}$ This choice reversed the choice made in the 1951 Treaty of Paris which created the European Coal and Steel Community (the EC precursor) that had kept most trade policy instruments under the control of the individual ECMS. The main exception to that rule was a then little known and used instrument-antidumping.

In the EC early decades, commercial policy was by far the most important of the four policies under exclusive competence. ${ }^{5}$ The EC competition policy seemed odd in the $1960 \mathrm{~s}$, when no other ECMS than Germany had a true competition policy. In fact some ECMS were looking at planning rather than markets as the ideal way to manage economies. The two other policies under exclusive competence (taxation issues related to the functioning of the customs union, and conservation of marine biological resources) were of more limited scope. The Common Agricultural Policy was shaped later (in the mid-1960s) and placed under "mixed competence" of the EC and the ECMS. ${ }^{6}$

\section{Extending the coverage of "exclusive competence" in trade in goods}

But the Treaty did not define precisely the instruments covered by commercial policy. It mentioned clearly only tariffs. Indeed, as early as the Kennedy Round (1964-1967) the Commission started to negotiate on tariffs on behalf of the ECMS (at that time the EC was nicknamed the "Geneva ghost") despite the fact that only the ECMS were GATT Members (the Treaty of Rome was notified to GATT, but not substantially reviewed by it). ${ }^{7}$

\footnotetext{
${ }^{4}$ A parallel could be made with the U.S., with the Council having the role of the U.S. Congress, and the Commission the role of the U.S. Administration.

${ }^{5}$ Since the creation of euro, the monetary policy is covered by exclusive competence for the ECMS members of the eurozone.

${ }^{6}$ Hence, "re-nationalizing" the CAP by the ECMS is a possibility which is not inconsistent with the Treaty.

${ }^{7}$ The Kennedy Round was instrumental to EC progress. It helped the ECMS with initially high tariffs to
} 
The progressive extension of exclusive competence to the other instruments of trade policy in goods - quotas of all types and other non-tariff barriers - was completed only at the end of the Uruguay Round (1995). This was the result of several converging evolutions. First, the European Court of Justice (hereafter, the Court) released several rulings (most notably, the 1976 Donckerwolcke ruling) which included non-tariff barriers in the EC commercial policy. Second, a Treaty provision (Article R115) allowed ECMS to impose barriers to imports of specified products into their own territory (these goods being imported freely in the rest of the EC) an alternative to EC-wide barriers. Its use was conditioned on a Commission's authorization that had to be renewed on a yearly basis, a condition which gradually made Article R115 obsolete. ${ }^{8}$ Third, in the late 1970s, the ECMS began to use a "European" facade for getting tailor-made trade barriers by using antidumping procedures (antidumping cases can be easily tailor-made to the interests of individual ECMS).

Last but not least, today, ECMS have still a last recourse to limit exclusive competence in goods. They can oppose changes in the EC commercial policy that they find contrary to their interests by vetoing, or threatening to veto, decisions in other EC policies that require unanimity or qualified majority of the ECMS. The "vetoing" ECMS would drop its opposition to the other policies if EC commercial policy was made favourable to its interests. That practice reduces de facto the scope of commercial policy within the competence of the EC.

As a result, the current situation remains somewhat fluid. For a vast majority of trade issues in goods, ECMS abide by exclusive competence, and tend to devolve trade policy to the Commission, to a point of giving the impression that the Commission is fully in charge. However, when a ECMS has a critical trade interest at stake, it can act precipitously and vigorously confront the Commission. This makes the EC trade policy more unpredictable than it used to be when ECMS were closely monitoring the Commission's actions, with the last months of important trade negotiations witnessing fierce intra-EC disputes on deals

enforce the cuts imposed by the Common External tariff by obtaining more open markets in the U.S. and other GATT Members.

${ }^{8}$ Article R115 became a mere paragraph in the Nice Treaty (Article N134) and is not included in the Functioning Treaty. 
tabled by the Commission. Solving such conflicts could require to give satisfaction to the ECMS, at the risk of blocking negotiations. It could also involve "compensation" to the "loosing" ECMS. For instance, at the end of the Uruguay Round, France dropped its opposition to the agreement by getting an additional package of farm subsidies from the other ECMS.

\section{$\underline{\text { Services and other commercial issues }}$}

If the Uruguay Round closed the debate on the Community's exclusive competence in trade in goods, it opened the debate on its exclusive competence in the other commercial issues that have been included in the world trade regime by the Uruguay Round (1995), in particular trade in services. Things continue to be complex in these matters.

Services are by far the most important issue in commercial policy: they constitute 70 percent of GDP in most ECMS and the core of future liberalization. Although written in 1955-1956 (few people thought about services at that time) Treaty Article R60 (F57) covers services, defined as economic activities "provided for remuneration, in so far as they are not [own emphasis] governed by the provisions relating to freedom of movement of goods, capital and persons". 9 As no country was interested in trade in services before the Uruguay Round negotiations, the Treaty provisions remained largely inert until the mid-1980s and early 1990s.

At the end of the Uruguay negotiations, the Court of Justice released its 1/94 opinion (November 1994) which has launched an official process of extending the Community's exclusive competence to commercial policy in services. The Lisbon Treaty solidifies such a competence in its Articles R131 (F206) and R133 (F207) by stating: "The Commission shall make recommendations to the Council, which shall authorise it to open the necessary negotiations. The Council and the Commission shall be responsible for ensuring that the agreements negotiated are compatible with internal Union policies and rules."

\footnotetext{
${ }^{9}$ The four freedoms (free movement of goods, services, people and capital) are the building blocks of the Treaty.
} 
Yet exclusive competence is much more difficult to implement in services where liberalization consists largely of regulatory reforms. In the $1970 \mathrm{~s}$, the hope that service regulations could be fully harmonized in the EC (a necessary condition for a meaningful concept of exclusive competence) collapsed. The following decades witnessed a constant retreat from this approach - from harmonization to mutual recognition, to mutual evaluation. As the ECMS are expected to stay in charge of regulatory reforms in services for a long time to go, mixed competence will de facto prevail. The apparent Community's exclusive competence combined with the reality of ECMS-based regulatory reforms in services generate an unsatisfactory situation for EC trading partners. They have to negotiate a trade agreement in services with the Commission, but most details of the negotiations and, even more crucially, the effective enforcement of the agreement need to be delivered by the ECMS.

The most important other commercial issues are public procurement, trade-related intellectual property rights, and foreign direct investment treaties. The first item leaves, by definition, a high degree of freedom to the ECMS, and even to the sub-national entities such as regions, provinces, and towns. As a result, the EC disciplines in this domain are mostly of procedural nature (transparency, non-discrimination, etc.).

The Lisbon Treaty includes foreign direct investment and TRIPs in the same Articles R131 (F206) and R133 (F207) that cover services. However, it is unclear to what extent these new provisions will be operational soon, particularly in foreign direct investment matters. During past decades, a few ECMS (notably Britain and Germany) have been able to develop a wide set of bilateral investment treaties that they may not be ready to make easily available to the other ECMS.

\section{Section 2. The level and costs of EC protection at the dawn of the Doha Round (2001)}

In the late 1990s, Lord Brittan, then Sir Leon Brittan the EC Trade Commissioner, floated the idea of a new Round of trade negotiations at the WTO that ultimately became the Doha Development Agenda (hereafter, the Doha Round for simplicity sake). This proposal marked 
a deep change in the EC approach to GATT Rounds. Until then, the EC initial position in new Rounds varied from cautious to reluctant, because many EC quarters perceived these Rounds as an attempt to dissolve the EC in a wider free trade area, hence as a obstacle to the long term political goal of European unification.

From a more economic perspective, Lord Brittan's proposal also surprised many Europeans who perceived the EC as a very open economy, compared to the other large economies. This belief was, and still is, best illustrated by the repeated assertions that the EC is the largest world importer, without recognizing that its sheer size and some features (such as the absence of EC territories capable of producing tropical crops) necessarily make it so. Yet at the dawn of the $21^{\text {st }}$ century the EC still has much protection.

\section{Protection of agriculture and manufacturing}

Tariff protection has two main dimensions: the average tariff level and the tariff dispersion allowing tariff "peaks" (defined in what follows as tariffs higher than 15 percent). From an economic perspective, tariff peaks cause most economic distortions, hence deliver the largest welfare gains to consumers when eliminated. They are also key from a political perspective because they are a sure sign of powerful lobbies, capable of protecting very inefficient sectors, even after more than five decades of liberalisation.

EC protection uses other instruments than ad valorem tariffs (tariffs expressed in percent of world prices). It includes:

- Specific tariffs, mainly tariffs expressed in euros per physical unit, which cover a third of the agricultural products.

- Quantitative import and export restrictions.

- Quotas enforced by the EC or "voluntary" restraints imposed by the EC but enforced by its trading partners.

- Antidumping measures, which can take the forms of ad valorem or specific tariffs, de facto voluntary quantitative export restraints or minimum price schemes.

- Safeguard measures, which can also take all of the above forms.

- Antisubsidy measures, which can take the forms of ad valorem or specific tariffs. 
- Production and export subsidies, massive in agriculture and,

- Norms and standards stringent enough to make difficult or impossible the import (or export) of foreign (EC) goods, as best illustrated by the ban of selling some genetically modified food.

It would be ideal to have estimates on the EC "global" protection which would aggregate all the above measures in one tariff-equivalent, expressed in percent of world prices for each product. But since this is not possible, the following estimates are limited to three instruments: ad valorem tariffs, ad valorem equivalent of antidumping measures and $a d$ valorem estimates of key quantitative import restrictions.

In Table 1, column 1 shows the average level of the EC global protection covering the above three instruments at the dawn of the Doha Round; and column 6 shows peak protection. Table 1 also compares these estimates with the ad valorem tariffs alone (columns 2 and 3 for the averages, columns 7 and 8 for the peaks) for the same year (1999) and for the most recent year. Finally, Table 1 provides the available data for China in order to get a sense of the relative speed of trade liberalization in the EC and in China (data on China are only on tariffs).

Table 1. Global border protection in the EC (2000 and 2008) and China (2001-2008)

\begin{tabular}{|c|c|c|c|c|c|c|c|c|c|c|}
\hline & \multicolumn{5}{|c|}{ Average border protection (\%) } & \multicolumn{5}{|c|}{ Maximum tariffs (\%) } \\
\hline & \multicolumn{3}{|c|}{ EC } & \multicolumn{2}{|c|}{ China [c] } & \multicolumn{3}{|c|}{ EC } & \multicolumn{2}{|c|}{ China [c] } \\
\hline & $\overline{1999[a]}$ & $1999[b]$ & 2008 & 2001 & 2007 & 1999 [a] & $1999[\mathrm{~b}]$ & 2008 & 2001 & 2005 \\
\hline & 1 & 2 & 3 & 4 & 5 & 6 & 7 & 8 & 9 & 10 \\
\hline Agricultural products & 24.1 & 17.3 & 17.2 & 23.1 & 15.3 & n.a. & 236.4 & 604.3 & 121.6 & 65.0 \\
\hline Manufacturing products & 7.7 & 4.5 & 3.7 & 14.4 & 8.8 & 41.7 & 26.0 & 89.8 & 90.0 & 50.0 \\
\hline All products & 11.7 & 6.9 & 6.7 & 15.6 & 9.7 & n.a. & 236.4 & 604.3 & 121.6 & 65.0 \\
\hline
\end{tabular}

Sources: [a] Messerlin [2001]. [b] WTO Secretariat, Trade Policy Review [2001 and 2009]. [c] WTO Secretariat, Trade Policy Review [2001, 2006 and 2008]. n.a.: not available. All averages are unweighted.

The table provides four main results. First, the level of EC global protection in 1999 is 11,7 percent - five percentage points above the ad valorem average tariff. This means that a substantial share of EC protection is delivered by opaque instruments (antidumping and quantitative restrictions) with well known perverse distortionary effects. 
Second, the Uruguay Round has only moderately reduced EC protection. Its impact has been notable in manufacturing with a decline of average global protection from 9.5 percent in 1990 to 7.7 percent in 1999. But it has been negligible in agriculture, in sharp contrast to a wide belief in Europe. EC farmers and politicians are wrong in attributing their problems to alleged farm liberalization of the Uruguay Round.

Third, columns 6 and 8 show that there remain severe tariff peaks in the EC (moreover, some of these peaks are based on specific tariffs which vary with world prices). Such high tariffs still protect a substantial share of the EC economies. In 1999, the level of global protection was higher than 10 percent in sectors representing more than one-fourth of the EC valueadded, and higher than 20 percent in sectors representing more than one-sixth of the EC value-added. The highly protected sectors are agribusiness (which is much more protected than farmers per se), chemicals, textiles and clothing, and, to a lesser extent, steel and cars.

Last but not least, Table 1 compares the EC to China in order to better understand the emerging world trade scenery. The average Chinese protection is becoming close to EC level-it is lower in agriculture, despite the fact that this sector represents a huge share of China's work force compared to 4 percent in Europe. This situation is all the more remarkable because China begun to liberalize only in the very late 1970s-early 1980s, thirty years after Europe started. Similar observations can be made about India or Brazil— though to a lesser extent, and with the key caveat that these countries apply tariffs much lower than the tariffs they bound at the WTO (hence they could increase their applied tariffs with no legal consequence in the WTO forum) while for China and the EC the bound and actual tariffs are the same. Chinese tariff dispersion tends to be smaller than the EC. The dramatic shifts in level and dispersion of protection of the major trading partners, with the emerging economies becoming rapidly as open as the EC and the U.S., explain the tectonic changes observed in the world economic relations during the last decade.

\section{$\underline{\text { Protection of services }}$}

Services represent about 70 percent of the European economy, but not all of them have been 
the main target of European integration since the mid-1980s. Treaty Article R63 (F59) provides that "priority [for liberalisation] shall as a general rule be given to those services which directly affect production costs or the liberalisation of which helps to promote trade in goods." As a result, the acquis communautaire (the set of EC-wide regulations, hereafter the acquis) in this sector is concentrated in a limited number of services, as illustrated by Table 2. In particular, the acquis in the mid-2000s does not include key services supplied by public entities in most of the ECMS such as health, education, as well as private services of huge economic importance including retail distribution, and tourism which were included only very recently in the acquis communautaire, with the 2006 Services Directive [Breuss et alii 2008].

Table 2. The acquis communautaire in services, mid-2000s

\begin{tabular}{|c|c|c|c|c|c|c|c|}
\hline & \multicolumn{6}{|c|}{ Number of texts } & \multirow{3}{*}{$\begin{array}{c}\text { All } \\
\text { (shares) } \\
(\%)\end{array}$} \\
\hline & 1958 & 1986 & 1991 & 1996 & 2001 & All & \\
\hline & 1985 & 1990 & 1995 & 2000 & 2005 & & \\
\hline Freedom of workers & 4 & & & 1 & 8 & 13 & 2,2 \\
\hline Right of establishment, freedom to provide services & 5 & 1 & & 3 & 1 & 10 & 1,7 \\
\hline Free movement of capital & 1 & 2 & 1 & 5 & 4 & 13 & 2,2 \\
\hline \multicolumn{8}{|l|}{ Financial services } \\
\hline Banking and financial conglomerates & & 1 & 2 & 5 & 2 & 10 & 1,7 \\
\hline Insurance and occupational pensions & 10 & 5 & 7 & 4 & 11 & 37 & 6,3 \\
\hline Securities markets and investment services & 1 & & 1 & 2 & 9 & 13 & 2,2 \\
\hline Others & & & & 1 & 10 & 11 & 1,9 \\
\hline \multicolumn{8}{|l|}{ Information society and media } \\
\hline Audiovisual Policy & & 2 & & 3 & 3 & 8 & 1,4 \\
\hline Electronic communications & & 2 & 2 & 7 & 39 & 50 & 8,6 \\
\hline Information Society Directive & & & & 4 & 2 & 6 & 1,0 \\
\hline \multicolumn{8}{|l|}{ Transport Policy } \\
\hline Land transport: road & 6 & 5 & 16 & 25 & 27 & 79 & 13,6 \\
\hline Land transport: rail & 1 & & 3 & 6 & 25 & 35 & 6,0 \\
\hline Inalnd waterways & 5 & 4 & 10 & 9 & 4 & 32 & 5,5 \\
\hline Maritime transport & 5 & 6 & 8 & 20 & 50 & 89 & 15,3 \\
\hline Air transport & & 1 & 17 & 21 & 49 & 88 & 15,1 \\
\hline State aid & 3 & 2 & 10 & 4 & 4 & 23 & 3,9 \\
\hline \multicolumn{8}{|l|}{ Energy } \\
\hline Electricity & & & & & 3 & 3 & 0,5 \\
\hline Gas & & & & & 3 & 3 & 0,5 \\
\hline Hydrocarbons & 4 & & 2 & 1 & & 7 & 1,2 \\
\hline Coal & & & & & 2 & 2 & 0,3 \\
\hline New and renewable sources of energy & 1 & & 2 & 2 & 10 & 15 & 2,6 \\
\hline Nuclear energy & 2 & 4 & 4 & 6 & 5 & 21 & 3,6 \\
\hline \multicolumn{8}{|l|}{ TransEuropean networks } \\
\hline Transport & & & 1 & 2 & 5 & 8 & 1,4 \\
\hline Energy & & & 1 & 3 & 3 & 7 & 1,2 \\
\hline Acquis communautaire in services & 48 & 35 & 87 & 134 & 279 & 583 & 100,0 \\
\hline in percent of total & 8,2 & 6,0 & 14,9 & 23,0 & 47,9 & 100,0 & \\
\hline
\end{tabular}

Source: EC legislation in force. Author's calculations.

The key question is: has this regulatory effort improved access to ECMS services by service providers from the rest of the world? Until the late 1990s, there was a naive feeling in the EC that adopting the acquis in services - the so-called 1992 Programme, then the Internal Market programme - would be sufficient to create an effective "Internal Market" in services, despite the robust evidence that it was not the case [Messerlin 2001]. It is only in the mid-2000s that the Commission recognized that creating an Internal Market was much less simple than 
expected.

That said, protection is much more difficult to document in services than in goods. What follows relies on three sources: data on trade in services, direct information on regulatory barriers in services, and on barriers to foreign direct investments, a key instrument for acceding to foreign markets in services.

Data on trade in services are notoriously incomplete, and a notable share is included in the data on trade in goods. Comparing intra-EC and extra-EC trade flows in services shows two main results. Between 1995 and 2005, the share of intra-EC and extra-EC trade in services in world trade has not changed much. During the same period, the GDP shares of intra-EC and extra-EC trade in services have increased, but roughly at the same rate as the GDP shares of intra-EC and extra-EC trade in goods [Gros 2007, Ilzkovitz et alii 2007].

A first direct information on market opening in services is provided by the OECD indicators on the product-market regulations (PMRs). ${ }^{10}$ Table 3 presents the evolution of these indicators for 1998, 2003 and 2008 for 26 OECD members, for various groups of ECMS and for a group of OECD "reference countries". It suggests three main results. First, the "founding" ECMS have slightly improved their average relative performance compared to the OECD reference countries between 1998 and 2003, but not since 2003. Second, other long-standing ECMS (Western ECMS \#2) have made no progress. Last but not least, the most recent ECMS (the Central European ECMS) have substantially reduced their regulatory backwardness, to the point of having caught up some long-standing ECMS (Western ECMS $\# 2)$.

In short, none of these results presents the acquis communautaire as an autonomous and vigorous source of services liberalization. Founding ECMS are not at the forefront of market openness, some long-standing-time ECMS are loosing ground while recently acceded ECMS are quickly catching up. These results are confirmed by other available databases on regulatory reforms [Messerlin 2007, 2008].

10 These indicators constructed by the OECD (which focus on the network sectors targeted by the Directives) range from 0 (most pro-market regulations) to 6 (least pro-market regulations) [Nicoletti 2000, Conway et al. 
Table 3. Product market regulations (PMR) indicators

\begin{tabular}{|c|c|c|c|c|}
\hline Group & Countries & 1998 & 2003 & 2008 \\
\hline $\mathrm{RC}$ & United States & 1.28 & 1.01 & 0.84 \\
\hline EW1 & Britain & 1.07 & 0.82 & 0.84 \\
\hline EW1 & Ireland & 1.65 & 1.35 & 0.92 \\
\hline $\mathrm{RC}$ & Canada & 1.29 & 1.14 & 0.95 \\
\hline EF & Netherlands & 1.66 & 1.36 & 0.97 \\
\hline EW2 & Spain & 2.55 & 1.68 & 1.03 \\
\hline EW1 & Denmark & 1.59 & 1.18 & 1.06 \\
\hline $\mathrm{RC}$ & Japan & 2.19 & 1.41 & 1.11 \\
\hline $\mathrm{RC}$ & Switzerland & 2.48 & 1.72 & 1.18 \\
\hline EW3 & Finland & 2.08 & 1.30 & 1.19 \\
\hline $\mathrm{RC}$ & Australia & 1.52 & 1.16 & 1.23 \\
\hline $\mathrm{RC}$ & New Zealand & 1.36 & 1.14 & 1.26 \\
\hline ECC & Hungary & 2.30 & 1.91 & 1.30 \\
\hline EW3 & Sweden & 1.93 & 1.49 & 1.30 \\
\hline EF & Germany & 2.06 & 1.60 & 1.33 \\
\hline $\mathrm{EF}$ & Italy & 2.59 & 1.81 & 1.38 \\
\hline EF & Belgium & 2.17 & 1.59 & 1.43 \\
\hline EW2 & Portugal & 2.25 & 1.64 & 1.43 \\
\hline EW3 & Austria & 2.33 & 1.76 & 1.45 \\
\hline EF & France & 2.52 & 1.75 & 1.45 \\
\hline $\mathrm{RC}$ & Korea & 2.35 & 1.78 & 1.47 \\
\hline EF & Luxembourg & -- & 1.48 & 1.56 \\
\hline ECC & Czech Republic & 2.99 & 1.98 & 1.62 \\
\hline ECC & Slovakia & -- & 1.84 & 1.63 \\
\hline ECC & Poland & 3.97 & 2.95 & 2.26 \\
\hline EW2 & Greece & 2.99 & 2.58 & 2.37 \\
\hline EF & Founding ECMS & 2.20 & 1.60 & 1.35 \\
\hline EW1 & Western ECMS \#1 & 1.44 & 1.12 & 0.94 \\
\hline EW2 & Western ECMS \#2 & 2.60 & 1.97 & 1.61 \\
\hline EW3 & Western ECMS \#3 & 2.11 & 1.52 & 1.31 \\
\hline $\mathrm{ECC}$ & Central ECMS & 3.09 & 2.17 & 1.70 \\
\hline $\mathrm{RC}$ & Reference countries & 1.78 & 1.34 & 1.15 \\
\hline
\end{tabular}

Source : OECD, Product Market Regulation Database (website). The indicators range from 0 (most pro-market regulations) to 6 (least pro-market regulations).

Finally, the international provision of services relies heavily on foreign direct investment (FDI). Table 4 presents the available direct evidence of restrictions in specific barriers to FDI flows as estimated by the OECD FDI restrictiveness indexes (FDIRIs). ${ }^{11}$ Table 4 shows a wide range of situations among ECMS. Only a few ECMS are very open to the rest of the world, and only those ECMS are likely to be also open vis-à-vis the other ECMS. By contrast, the ECMS with high FDIRIs with respect to the rest of the world are likely to be also close vis-à-vis the other ECMS for the services in question.

2005].

${ }^{11}$ These indicators constructed by the OECD range from 0 (most pro-market regulations) to 6 (least pro-market regulations). 
Table 4. Foreign direct investment restrictiveness indexes, 2006

\begin{tabular}{|c|c|c|c|c|c|c|c|c|c|c|c|c|c|c|c|c|}
\hline & & 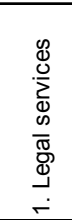 & 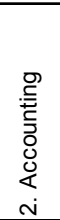 & 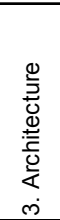 & 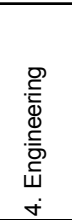 & 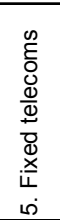 & 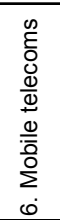 & 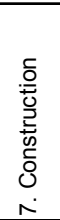 & 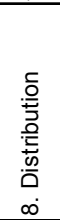 & 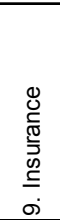 & 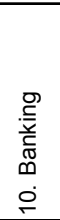 & 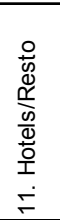 & 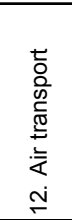 & 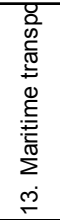 & 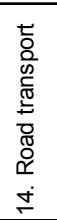 & 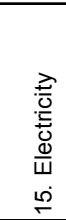 \\
\hline$\overline{E F}$ & Belgium & 22 & 22 & 22 & 22 & 72 & 72 & 22 & 22 & 44 & 44 & 22 & 122 & 248 & 72 & 22 \\
\hline EF & France & 233 & 33 & 33 & 33 & 72 & 72 & 22 & 22 & 138 & 94 & 22 & 198 & 198 & 72 & 322 \\
\hline EF & Germany & 22 & 22 & 22 & 22 & 122 & 122 & 22 & 22 & 116 & 72 & 22 & 248 & 198 & 22 & 122 \\
\hline $\mathrm{EF}$ & Iraly & 22 & 22 & 22 & 22 & 72 & 72 & 22 & 22 & 88 & 144 & 22 & 494 & 66 & 22 & 122 \\
\hline $\mathrm{EF}$ & Netherlands & 11 & 11 & 11 & 11 & 11 & 11 & 11 & 11 & 55 & 33 & 11 & 411 & 355 & 11 & 611 \\
\hline EW1 & Britain & 17 & 17 & 17 & 17 & 17 & 17 & 17 & 17 & 83 & 67 & 17 & 267 & 361 & 17 & 17 \\
\hline EW1 & Denmark & 1000 & 562 & 22 & 22 & 72 & 72 & 22 & 22 & 44 & 22 & 22 & 422 & 22 & 122 & 122 \\
\hline EW1 & Ireland & 22 & 22 & 22 & 22 & 122 & 122 & 22 & 22 & 88 & 44 & 22 & 466 & 66 & 22 & 1000 \\
\hline EW2 & Greece & 462 & 506 & 462 & 462 & 122 & 122 & 22 & 22 & 88 & 88 & 22 & 522 & 254 & 22 & 1000 \\
\hline EW2 & Portugal & 22 & 66 & 22 & 22 & 122 & 122 & 22 & 22 & 116 & 172 & 22 & 1000 & 122 & 22 & 122 \\
\hline EW2 & Spain & 512 & 66 & 22 & 22 & 322 & 322 & 22 & 22 & 226 & 182 & 22 & 304 & 316 & 22 & 22 \\
\hline EW3 & Austria & 348 & 348 & 348 & 348 & 172 & 172 & 172 & 172 & 272 & 172 & 172 & 322 & 472 & 222 & 172 \\
\hline EW3 & Finland & 550 & 550 & 110 & 110 & 110 & 110 & 110 & 110 & 110 & 160 & 110 & 310 & 210 & 154 & 210 \\
\hline EW3 & Sweden & 556 & 292 & 66 & 66 & 166 & 166 & 66 & 66 & 116 & 116 & 66 & 316 & 266 & 166 & 166 \\
\hline ECC & Czech Rep & 125 & 375 & 50 & 50 & 50 & 50 & 100 & 50 & 150 & 150 & 50 & 450 & 100 & 100 & 450 \\
\hline ECC & Estonia & 1000 & 22 & 22 & 22 & 22 & 22 & 22 & 22 & 122 & 22 & 22 & 322 & 366 & 22 & 622 \\
\hline ECC & Hungary & 100 & 100 & 100 & 100 & 200 & 100 & 100 & 100 & 150 & 100 & 100 & 500 & 400 & 150 & 200 \\
\hline ECC & Latvia & 0 & 0 & 0 & 0 & 0 & 0 & 0 & 0 & 0 & 0 & 0 & 132 & 0 & 100 & 1000 \\
\hline ECC & Lithuani & 50 & 50 & 50 & 50 & 50 & 50 & 50 & 50 & 50 & 100 & 50 & 350 & 94 & 50 & 650 \\
\hline ECC & Poland & 225 & 175 & 75 & 75 & 375 & 375 & 75 & 75 & 75 & 325 & 75 & 375 & 75 & 125 & 175 \\
\hline ECC & Romania & 250 & 50 & 50 & 50 & 150 & 150 & 50 & 50 & 50 & 175 & 50 & 750 & 150 & 50 & 450 \\
\hline ECC & Slovakia & 75 & 375 & 75 & 75 & 72 & 72 & 72 & 72 & 172 & 172 & 72 & 372 & 122 & 72 & 322 \\
\hline ECC & Slovenia & 125 & 125 & 100 & 100 & 200 & 100 & 100 & 100 & 100 & 100 & 100 & 740 & 244 & 100 & 700 \\
\hline$\overline{E C 27}$ & All ECMS & 250 & 166 & 75 & 75 & 117 & 108 & 50 & 48 & 107 & 111 & 48 & 408 & 205 & 76 & 374 \\
\hline $\mathrm{RC}$ & Japan & 100 & 100 & 25 & 25 & 286 & 25 & 25 & 25 & 25 & 75 & 25 & 675 & 275 & 25 & 25 \\
\hline $\mathrm{RC}$ & United States & 75 & 25 & 25 & 25 & 25 & 25 & 25 & 25 & 175 & 275 & 25 & 650 & 275 & 25 & 125 \\
\hline$\overline{E F}$ & Foundi & 62 & 22 & 22 & 22 & 70 & 70 & 20 & 20 & 88 & 77 & 20 & 295 & 213 & 40 & 240 \\
\hline EW1 & Western ECMS \#1 & 346 & 200 & 20 & 20 & 70 & 70 & 20 & 20 & 72 & 44 & 20 & 385 & 150 & 54 & 380 \\
\hline EW2 & Western ECMS \#2 & 332 & 213 & 169 & 169 & 189 & 189 & 22 & 22 & 143 & 147 & 22 & 609 & 231 & 22 & 381 \\
\hline EW3 & Western ECMS \#3 & 485 & 397 & 175 & 175 & 149 & 149 & 116 & 116 & 166 & 149 & 116 & 316 & 316 & 181 & 183 \\
\hline ECC & Central ECMS & 217 & 141 & 58 & 58 & 124 & 102 & 63 & 58 & 97 & 127 & 58 & 443 & 172 & 85 & 508 \\
\hline
\end{tabular}

Source : OECD [2007]. The indexes measure deviations from "national treatment" on a 0 to 1000 scale, with 0 representing full openness and 1000 a prohibition of FDI. GDP-weighted averages for the groups of ECMS.

Table 4 also shows substantial differences in the openness level of the three large economies (EC, Japan, U.S.) with the EC27 being the least open, except in air and maritime transport (compared to both Japan and the U.S.) banking and insurance (compared to the U.S.) and fixed telecom and accounting (compared to Japan).

\section{The costs of EC protection: estimates}

There are two alternative methods to estimate the costs of EC protection. The first concentrates on the peaks of protection. This requires the use of a partial equilibrium approach since available data do not allow the use of a general equilibrium approach when focusing on the precise goods subjected to peaks. Such an approach [Messerlin 2001] can 
cover a relatively wide set of trade barriers, take into account some consequences of imperfect competition, and cover some services. It suggests two main results: protection costs are close to 5 percent of the value-added of the sectors under scrutiny, if markets are assumed competitive; these costs increase to 7 percent of the EC GDP if imperfect competition, widely spread in services, is taken into account.

The second alternative is to adopt a general equilibrium approach which allows for key interactions between sectors and operators. But, it relies on trade-weighted measures of protection to aggregate the information into a manageable set of sectors, an approach which systematically underestimates tariff peaks, hence the costs of protection. As a result, these models suggest a much lower welfare cost of EC protection (generally less than one percent).

These results call for two additional remarks. First, the EC protection is inefficient: it saves a limited number of jobs at a much higher costs than the average wage in the sectors in question. This conclusion is reinforced by the following fact. As most ECMS have relatively inefficient labor markets, the number of jobs truly saved by trade barriers per se is probably even lower since these jobs would have been protected anyway by existing labor regulations. As shown by economic analysis, saving jobs requires much better targeted and monitored policies than trade policy.

Second, the EC protection tends to generate high rents to the protected sectors. Such rents are estimated to represent a third of the global cost of protection (compared to a fifth or a fourth for tariff revenues) [Messerlin 2001]. Such a high share is due to the fact that the EC markets where protection is high (steel, chemicals, food products, etc.) are also characterized by a relatively low level of competitive pressures which result from a mix of a tight net of regulations and of a widespread tendency to collusive behavior [Amatori 1999]. The large share of rents runs against the general perception of protection in the European opinion which often sees protection as protecting "public interest", and opening the economy as favouring narrow private interests. The reality is quite the opposite. Protection favours the "happy few", to the detriment of a much wider crowd of consumers and producers.

Last but not least, the costs of EC protection may be larger than those in comparably large 
industrial countries because the Internal Market in goods and services remains so imperfect. In 2005, price dispersion among the 15 oldest ECMS is still substantial, with a coefficient of variation of 13 percent for goods (down from 20 percent in 1991) and 36.2 percent in services [Ilzkovitz et al. 2007]. During the 1997-2006 period, 8 manufacturing sectors and 7 services sectors (out of 11 manufacturing sectors and 12 services sectors) showed notable to substantial signs of "integration problems" [Ilzkovitz et al. 2008].

\section{Section 3. The EC commercial policy in the 2000s}

In the late 1990s, the EC Commission became a champion of new WTO trade negotiations. However, it was very slow to realize the profound changes in the world situation that occurred in the $2000 \mathrm{~s}$ - particularly, the increasingly cooler U.S. attitude towards trade liberalization and the rising influence of the emerging economies, and their insistence on opening the U.S. and EC markets for products of interest to them-precisely those which have been most protected during the previous decades.

The Doha Round negotiations are moving at a slow pace, if at all since December 2008. This has induced the EC commercial policy to pay more attention to preferential trade agreements (hereafter, PTAs) under the form of bilateral agreements (hereafter, bilaterals). The EC renewed interest in bilaterals is driven by two very different motives from those which were behind its staunch support to PTAs until the late 1980s. First is a foreign policy motive. The EC fell behind the U.S. initiatives in terms of bilaterals, negotiated or signed with countries in the Middle East, in Latin America or in Asia Pacific, which were largely driven by political reasons. The second motive was a desire to change radically the logic of the PTAs with the African, Caribbean and Pacific countries (ACPs), which are the oldest PTAs in the history of the EC commercial policy.

\section{The Doha Round}

The EC, as was the U.S., has entered the Doha negotiations with a mentality of "business as usual". It considered itself the dominant player along with the U.S., so that it could trade small opening of its agricultural markets for concessions in topics that it was not able to settle 
during the Uruguay Round (1995) although it priced them highly: geographical indications in agriculture, ${ }^{12}$ competition policy, rules in investment and public procurement, trade facilitation to mention the most important ones.

The 2003 Cancun Ministerial eliminated these topics from the Doha list of topics to be negotiated, with the exception of trade facilitation, and more problematically geographical indications. It was only then that the EC fully realized that opening its agricultural markets was the key condition to get more open industrial markets in the developing and emerging countries.

The Doha negotiations took shape only at the 2005 Hong Kong Ministerial. They have led to the Doha "modalities" released in December 2008 by the Chairs of the agriculture and NAMA WTO negotiating groups. What follows refers to these "2008 Doha texts" because they are seen as the "best approximation" of what could be the final results of the Doha Round.

\section{Negotiations in industrial products (NAMA)}

In the negotiations on industrial products ("non-agricultural market access" in the Doha Round jargon, hereafter NAMA) the EC is mostly a demandeur since its own level of protection is generally low with the exception of peak tariffs. The 2008 Doha texts would imply that the EC average tariff would be reduced from 3,7 to just above 3 percent, while EC peak tariffs would be sharply cut, from 50 to less than 8 percent.

Turning to the tariffs of the EC trading partners, the European manufacturing sector was looking for a simple outcome of the Doha Round: "no single [industrial] tariff above 15 percent at the end of the implementation period, except for $L D C$ )" [Businesseurop/UNICE 2001]. The 2005 Hong Kong Ministerial adopted a "Swiss" formula as the formula for cutting tariffs. ${ }^{13}$ The Businesseurop request would require the adoption of a Swiss

\footnotetext{
${ }^{12}$ Geographical indications are place names (or words associated with a place) used to identify the origin and quality, reputation or other characteristics of products.

${ }^{13}$ The basic Swiss formula is $\mathrm{T}=[\mathrm{r} t /(\mathrm{r}+\mathrm{t})]$ where ' $\mathrm{t}$ ' is the initial tariffs, ' $\mathrm{T}$ ' the post-negotiation tariffs, and ' $\mathrm{r}$ ' the reduction coefficient (hereafter the "Swiss coefficient"). The Swiss coefficient is thus the only element to be 
coefficient of 18 to 20 by the EC major trading partners. The current Swiss coefficients mentioned in the 2008 Doha texts, ranging from 20 to 25 , are close to satisfy this request, except for a small number of tariff lines [Messerlin 2011].

But this result still depends on the exceptions to the Swiss formula that the 2008 Doha texts will offer to the developing countries. Some exceptions (in particular, the possibility to keep unbound tariffs or to impose no cuts on 5 to 7.5 percent of the tariff lines) could seriously reduce the very positive impact of the above-mentioned Swiss coefficients.

Second, Swiss coefficients ranging from 20 to 25 mean that developing countries would mostly bind their tariffs at their current level; that is, would eliminate the existing "water in tariffs" (the difference between bound and applied tariffs). Henceforth, developing countries would no longer have the option of raising their applied tariffs to their bound tariffs. Such a reversal was very much feared at the peak of the 2008-2009 crisis, and it would have cost 450 to 900 billion dollars to the world GDP [Bouët and Laborde 2009, Productivity Commission 2009].

Such cuts of bound tariffs would not change drastically the existing level of openness of the emerging markets, which are de facto relatively open. So it does not create great enthusiasm among European businesses. But, although the offensive interests of European business have largely been achieved (assuming only few exceptions to the Swiss formula) the EC negotiators are continuing to insist on getting more concessions in NAMA from the emerging economies. They have two opposite reasons for such a tactic. By doing so, they may try to open more the NAMA markets of the emerging economies. But they may also try to limit the opening of the EC agricultural markets, because demanding more concessions in NAMA may be a way to induce the emerging countries to demand less concessions in agriculture.

\section{Negotiations in "agriculture"}

The term "agriculture" in the Doha Round is a misnomer. The current negotiations deal with three times as many agro-industrial or "food" products as farm products. This little 
recognized feature is crucial because trade liberalization in food products is likely to be similar to trade liberalization in industrial products, and could therefore benefit from the long experience in the latter.

Negotiations on tariffs. Largely under the EC influence, the Doha negotiators on farm and food products have adopted a liberalization formula, known as "tier-based" formula, which is much more opaque than the Swiss formula. ${ }^{14}$ A tier-based formula has also the key shortcoming of cutting the initially high tariffs by less than a Swiss formula. Yet, from an economic perspective, the tariffs that should be cut most are the high tariffs which generate the highest welfare costs.

Table 5 provides the tariff cuts to be expected from the 2008 Doha text for the whole agricultural sector and for its farm and food components. ${ }^{15}$ It shows the strong "tariff escalation" in the current EC schedule: the more processed the goods are, the higher their level of protection. The average tariff of bulk farm products (19.7 percent) is substantially lower than the average tariff of the processed food products (32.6 percent), and, even more strikingly, the highest tariff for farm products (93.6 percent) is much smaller than the highest tariff on processed food (407.8 percent).

Secondly, as the Doha tier-based formulas are softer on the highest tariffs than the Swiss formulas, the tariff cuts in the current EC proposal protect food producers much more often than farmers. Table 5 shows that the post-Doha tariffs would be 7.8 percent for the bulk farm commodities compared to 12.3 percent for processed food products, while the post-Doha maximum tariff would be 28.1 percent for the farm products, compared to 122.3 percent for processed food. Moreover, the food products that would remain the EC's most protected items after the Doha Round are a strange hodgepodge of waste products (dog and cat food, offal, whey, etc) goods with a tiny potential in international trade (yoghurts) and products of questionable importance (cucumbers, gherkins, etc).

\footnotetext{
${ }^{14}$ A tier-based formula splits the whole range of the existing tariffs into several tiers (4 to 5 in the Doha Round). Tariffs pertaining to a tier are cut by a constant percentage. For instance, in the case of developed countries, tariffs ranging from 0 to 20 percent would be cut by 50 percent, while those ranging from 20 to 50 percent would be cut by 57 percent, etc.

${ }^{15}$ The concordance table used has been established by the US Department of Agriculture. It splits the whole universe of the "agricultural" products into four subsets: the bulk farm commodities, the produce/horticulture
} 


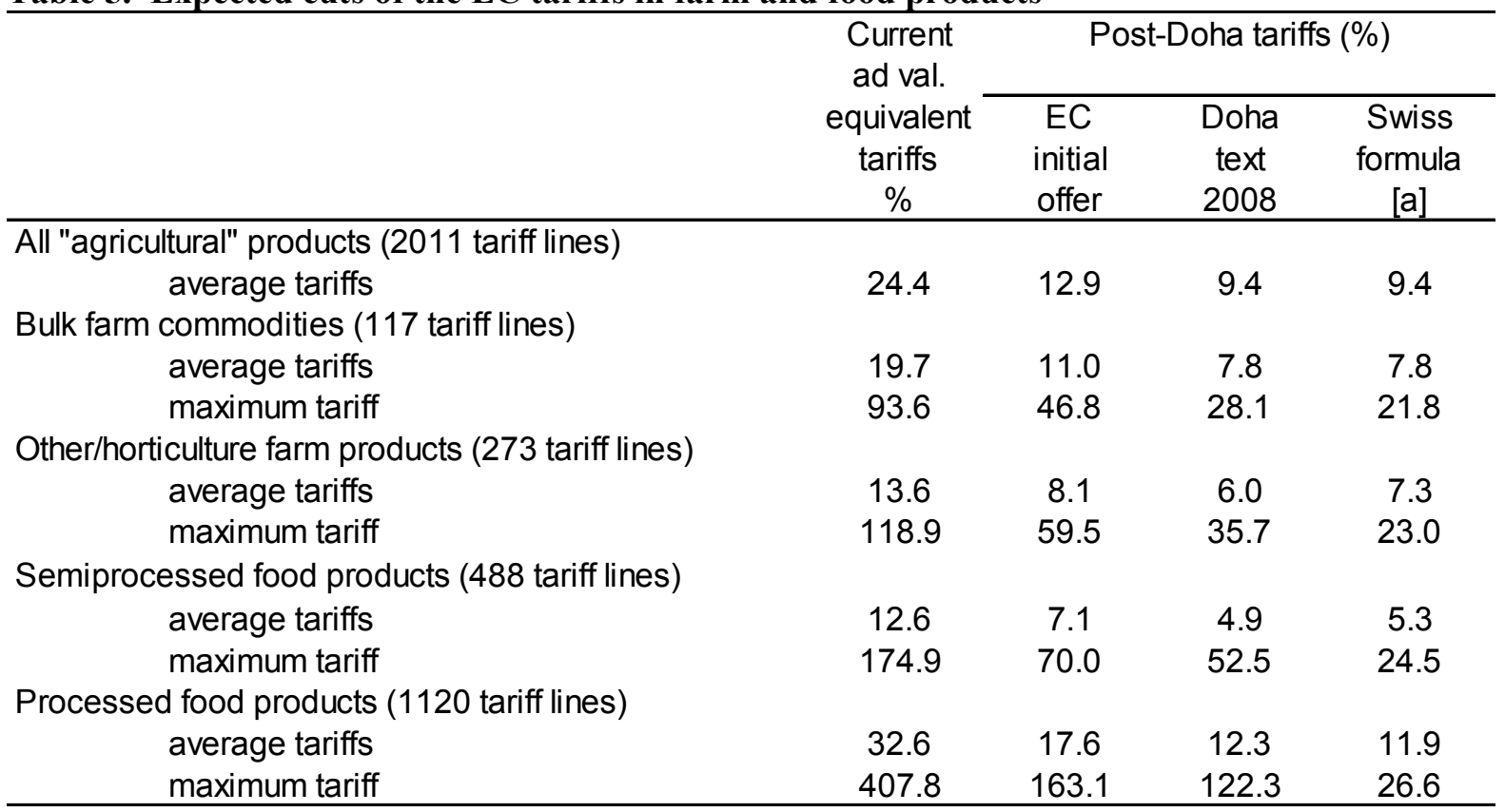

Source: EC tariff schedule, including the ad valorem equivalents of the specific tariffs. Note: The Swiss coefficient of 28.5 would ensure that the average tariff on all the farm and food products is the same as the tariff generated by the tier-based formula suggested by the 2008 Doha texts $(9,4$ percent).

As in NAMA, the 2008 Doha texts on agriculture raise serious problems because they provide too generous exceptions to tariff cuts, hence risking unravelling the impact of the tier-based formula. In the same vein, the EC has been pushing hard for an intensive use of "tariff-rate quotas" as the preferred instrument for exceptions. Tariff-rate quotas are well known for their opacity and their perverse effects. The quota rents they generate are likely to go not to European farmers, but rather to EC-based importing firms or even to foreign exporting firms.

Negotiations on farm subsidies. If tariffs cover farm and food products, subsidies are concentrated on farm products. In the EC system, some agrifood firms may receive subsidies, particularly export subsidies. But these subsidies are mostly compensation for high prices of the farm products that these agrifood firms have to pay European farmers. In short, EC agribusiness firms are "quasi-public" agencies for distributing subsidies to the farmers. 
The EC has been in a better negotiating position in the Doha negotiations on farm subsidies than the U.S. because, since 2004, it has shifted roughly Euros 25 billions out of the perimeter of the prohibited subsidies ("overall trade distorting support" in the Doha jargon). ${ }^{16}$ Indeed, Table 6 shows that the 2008 Doha texts would essentially bind the EC and U.S. future subsidies at the current or shortly expected within a few years level. In short, the huge "water in domestic support" would be largely eliminated - echoing the above-mentioned elimination of the huge "tariff water" in NAMA for the emerging economies.

Yet serious problems remain. First, subsidies outside the coverage of the "overall trade distorting support" may be less perverse than production-based subsidies, but they still have an indirect impact on trade flows. Hence, they should be revisited. This perspective fits well the growing recognition in Europe that decoupled farm subsidies go mostly to large farmers for which few Europeans want to fight, hence are facing an increasing legitimacy problem. With time it will become increasingly unsustainable politically to grant subsidies to farmers on the basis of outputs produced in an increasingly distant past.

Table 6 The liberalization formulas in the "overall trade distorting support" (OTDS)

\begin{tabular}{lcccc}
\hline & \multicolumn{2}{c}{ Support in } & \multicolumn{2}{c}{ Support in \% of } \\
& billion US dollars [a] & \multicolumn{2}{c}{ agricultural output [b] } \\
& U.S. & EC15 [c] & U.S. & EC15 \\
\hline The Uruguay bound commitments & 55.0 & 149.0 & 47.4 & 70.6 \\
Effective OTDS (2004) & 23.0 & 78.0 & 19.8 & 37.0 \\
Estimated OTDS (2013) [d] & 12.4 & 30.0 & 10.7 & 14.2 \\
The Doha draft text (December 2008) & & & & \\
$\quad$ Base levels & 48.2 & 149.0 & 41.6 & 70.6 \\
$\quad$ Formula cuts (in \%) & 70 & 80 & -- & - \\
$\quad$ Commitments & 14.5 & 29.8 & 12.5 & 14.1 \\
\hline
\end{tabular}

Source: WTO Agriculture Chair text, TN/AG/W/\$/Rev.4, 6 December 2008. Author's computations. Notes: The overall trade distorting support includes all the farm subsidies deemed to be highly trade distortive. (a) Figures for the EC are expressed in euros in the Chair text, and are translated in U.S. dollars on the basis of an exchange rate of 1.35 U.S. dollar per euro prevailing in December 2008. (b) Average value added in agriculture for the years 1995-2000. (c) Past figures for the OTDS for the EC 27 are roughly 106 percent higher than those for the EC15. OTDS for 2013 is estimated for the whole EC27. (d) Support for 2013 are estimated by Kutas (2010) for the EC and by Orden, Josling and Blandford (2010) for the U.S..

Second, recent years have witnessed worrisome developments in certain EC subsidy

\footnotetext{
${ }^{16}$ For simplicity sake, this note refers only to the "overall trade distorting support", but the 2008 Doha texts include other disciplines on subsets of different types of subsidies (see Kutas [2010], Orden, Josling and
} 
schemes: the huge subsidies granted to biofuels leading to effective rates of protection of almost 10,000 percent, despite the fact that such biofuels of the first generation have a strong negative impact on environment; the emergence of antidumping measures in agriculture (on biofuels imported from the U.S.); and the re-activation of export subsidies for dairy since the 2008-2009 economic crisis.

A concluding remark on agriculture. Whether the Doha negotiations fail or succeed, they have achieved an important objective in the EC farm sector. They have made European farmers and policy-makers increasingly aware of the fact that the impact of the Common Agricultural Policy varies with each Member state's production structure. A ECMS producing mostly farm goods protected by high EC tariffs and/or subsidies is, on average, "more" protected than a ECMS producing mostly farm goods protected by low or moderate EC tariffs or subsidies.

Table 7. Level of protection by EC Member States, 2004

\begin{tabular}{|c|c|c|}
\hline EC Member States & $\begin{array}{c}\text { Global } \\
\text { protection }\end{array}$ & $\begin{array}{c}\text { Tariffs } \\
\text { (\%) } \\
\text { [b] }\end{array}$ \\
\hline Ireland & 91 & 26.2 \\
\hline Luxemburg & 69 & 25.6 \\
\hline Britain & 66 & 25.5 \\
\hline Finland & 65 & 26.5 \\
\hline Sweden & 65 & 25.5 \\
\hline Lithuania & 58 & 26.6 \\
\hline Germany & 56 & 24.5 \\
\hline Latvia & 56 & 25.3 \\
\hline Austria & 55 & 22.9 \\
\hline France & 55 & 21.6 \\
\hline Czech Republic & 54 & 26.6 \\
\hline Belgium & 53 & 22.7 \\
\hline Slovenia & 52 & 21.2 \\
\hline Estonia & 51 & 27.2 \\
\hline Slovakia & 51 & 25.2 \\
\hline Netherlands & 50 & 19.1 \\
\hline Denmark & 49 & 26.1 \\
\hline Poland & 45 & 24.5 \\
\hline Hungary & 41 & 23.5 \\
\hline Italy & 41 & 19.1 \\
\hline Spain & 41 & 19.1 \\
\hline Portugal & 40 & 18.3 \\
\hline Greece & 37 & 18.7 \\
\hline Malta & 35 & 18.6 \\
\hline EC (16 Member States) & 51 & 21.9 \\
\hline EC (24 Member States) & 57 & 23.3 \\
\hline
\end{tabular}

Sources: OECD, WTO. Notes: [a] PSE: producer surplus equivalent, as calculated by the OECD. [b] Ad valorem tariffs in 2004 (specific tariffs excluded). It is impossible to update these results because the European 
agricultural policy has been increasingly modulated by the ECMS since 2004 .

Table 7 illustrates this point by weighting each ECMS' farm production by the EC-wide level of protection, be it measured by tariffs or by the combined protection granted by tariffs and subsidies as measured by the OECD "producer support equivalents". It shows that PSEs vary from one to 2,6 and tariffs from one to 1,4 .

Contrary to common belief, French farmers are not among the most protected in the EC: farmers from ECMS favouring freer trade (Britain or Sweden for instance) are on average more protected. This situation should induce French farmers to be among the most supportive of market opening in agriculture since a large share of French agriculture is not protected by the Common Agricultural Policy, and since, for those protected farm products, French farmers are often considered among the most efficient in Europe.

\section{The other topics included in the Doha Round}

The Doha Round negotiations cover potentially many other important topics: services; selected industrial sectors (such as environmental products and equipment goods) which are candidates for full liberalization, including non-tariff barriers; geographical indications; rules for antidumping and antisubsidy; and trade facilitation. But so far all these topics except trade facilitation have not been subjected to intensive negotiations because the Doha negotiators have agreed to a sequential approach — first negotiate on industrial and agricultural goods then on the other topics. As a result, the EC and all the other developed countries have no visibility on what are the opportunities and gains to be expected in services, when these activities represent 70 percent of EC GDP and may be the source of substantial comparative advantages. This sequential approach has been detrimental to a rapid and successful conclusion of the Doha Round.

\section{$\underline{\text { Back to preferential trade agreements }}$}

In November 2006, Lord Mandelson, the then Trade Commissioner, released a working document on "Global Europe" reaffirming the EC support to the Doha negotiations, but also developing a massive European strategy of future bilaterals (no less than 24) hence giving a 
strong impression of a deep change in the EC commercial policy [European Commission 2006]. It seemed that the EC was going back to its "addiction" to discrimination which marked its trade policy from the 1960s to the 1990s, a policy that has left deep scars in the world trade system: a third of the current PTAs notified to the WTO are intra-European bilaterals, mainly deals between countries located on the European continent. This large number mirrors the way Europeans are building their Single Market: any new bilateral negotiated by the EC generates mechanically "clone" negotiations by the European countries linked to the EC by trade agreements - the EFTA countries, Turkey, etc.

However, the Global Europe document suggests that the new bilaterals have a new raison d'être, namely a substantial foreign policy component. This aspect explains the Commission's repeated statement that the EC is lagging behind in terms of bilaterals. This perception was largely created by the fact that most recent U.S. bilaterals were politically loaded. ${ }^{17}$

The fact that the motive behind the Global Europe agenda is largely "political" raises a key question. Would the bilaterals envisaged by the EC be dominated by "market opening" forces or by "market preference" forces? The former case occurs when negotiating countries apply low tariffs on goods imported from countries other than the signatories of the deal and enforce domestic pro-competitive regulations on services and investment. Such bilaterals are likely to have a net positive economic effect on the signatories, and no significant negative impact on the rest of the world. They may be stepping stones to world trade liberalization and, by the same token, enhance EC political influence without costing much to the EC or its PTA partners.

By contrast, market preferences-dominated bilaterals, namely high tariffs on goods imported from the rest of the world and anti-competitive domestic regulations on services and investment are likely to be economically harmful. The higher the preferences, the more

\footnotetext{
${ }^{17}$ The US Administration has taken few initiatives in terms of bilaterals (Australia, Korea, Latin America) and these were fundamentally driven by foreign policy motives (from the Iraq war to the drug wars). At this juncture, the U.S. has no pending "grand vision" of bilaterals. The Free Trade Area for the Americas looks like a sleeping beauty, the U.S. calls for an Asian Pacific initiative are incantatory but inconsequential. Lastly, the ordeals to get the recent bilaterals approved by the U.S. Congress and the mood of the newly elected Congress (revealed by the request for a review of the bilaterals demanded by the new Democratic majority) do not suggest
} 
distorted the bilateral trade flows that result, and the higher the costs of the bilateral deal consumers of the products and services imported from the trading partner. Hence, the higher the likelihood of the collapse of the bilateral agreement, and the more painful the "erosion" of these preferences would be for the signatories. If such bilaterals are likely to be stumbling stones to world trade opening, then they are politically costly to the EC, and perhaps to its partners as well.

Table 8 compares the EC bilateral policy, when launched in 2006, with the equivalent policies of six other countries. It gives - in an admittedly crude way - a sense of the "market opening" vs. "market preference" nature of the 91 bilaterals signed by these countries in 2006, and of the 100 bilaterals under negotiation or under consideration by these seven countries.

Table 8. Comparing Global Europe to the strategies of other selected countries, 2006

\begin{tabular}{|c|c|c|c|c|c|c|c|c|c|c|}
\hline & \multirow{3}{*}{$\begin{array}{c}\text { Number } \\
\text { of } \\
\text { partners }\end{array}$} & \multicolumn{2}{|c|}{ Market size [a] } & \multirow{2}{*}{\multicolumn{2}{|c|}{$\begin{array}{c}\text { Average industrial } \\
\text { tariff }[\mathrm{b}]\end{array}$}} & \multicolumn{5}{|c|}{ Regulatory ranking [c] } \\
\hline & & \multirow{3}{*}{$\begin{array}{c}\text { at } \\
\text { current } \\
\text { USD }\end{array}$} & \multirow{3}{*}{$\begin{array}{l}\text { at } \\
\text { PPP } \\
\text { USD }\end{array}$} & & & \multirow{3}{*}{$\begin{array}{l}\text { trading } \\
\text { across } \\
\text { borders }\end{array}$} & \multirow{3}{*}{$\begin{array}{l}\text { dealing } \\
\text { with } \\
\text { licences } \\
7\end{array}$} & \multirow{3}{*}{$\begin{array}{l}\text { ease of } \\
\text { doing } \\
\text { business } \\
8\end{array}$} & \multirow{3}{*}{$\begin{array}{l}\text { regis- } \\
\text { tering } \\
\text { property } \\
9\end{array}$} & \multirow{3}{*}{$\begin{array}{c}\text { protec- } \\
\text { ting } \\
\text { investors } \\
10\end{array}$} \\
\hline & & & & applied & bound & & & & & \\
\hline & 1 & & & 4 & & & & & & \\
\hline \multicolumn{11}{|c|}{ A. Bilaterals signed } \\
\hline Singapore & 10 & 48.5 & 39.3 & 4.8 & 9.2 & 35.8 & 41.7 & 28.0 & 35.3 & 16.7 \\
\hline Chile & 20 & 79.0 & 70.4 & 5.5 & 8.0 & 34.1 & 70.8 & 41.5 & 39.6 & 46.3 \\
\hline Korea & 14 & 4.1 & 5.8 & 7.1 & 21.5 & 58.8 & 70.3 & 69.0 & 59.2 & 68.7 \\
\hline USA & 15 & 7.6 & 6.5 & 7.5 & 19.6 & 42.9 & 41.9 & 29.2 & 50.1 & 34.0 \\
\hline China & 14 & 2.9 & 5.9 & 8.0 & 25.4 & 63.1 & 77.3 & 72.8 & 66.7 & 55.4 \\
\hline EC & 14 [d] & 6.4 & 8.2 & 9.2 & 18.3 & 76.8 & 91.9 & 67.1 & 80.4 & 53.4 \\
\hline Japan & 4 & 2.7 & 3.3 & 10.0 & 27.4 & 69.4 & 62.4 & 55.6 & 76.6 & 52.4 \\
\hline \multicolumn{11}{|c|}{ B. Bilaterals under negotiations or consideration } \\
\hline Singapore & 12 & 90.6 & 81.2 & 5.7 & 9.0 & 40.0 & 68.9 & 43.5 & 42.3 & 41.0 \\
\hline Chile & $9[e]$ & 81.6 & 77.7 & 6.4 & 10.3 & 43.2 & 77.8 & 49.4 & 45.5 & 45.1 \\
\hline Korea & 11 & 49.1 & 57.4 & 7.3 & 13.3 & 43.3 & 85.3 & 57.6 & 39.8 & 40.4 \\
\hline Japan & 18 & 13.4 & 16.4 & 7.5 & 20.0 & 53.5 & 58.3 & 54.8 & 60.6 & 56.6 \\
\hline USA & 14 & 14.9 & 16.5 & 8.8 & 21.3 & 54.1 & 69.7 & 52.2 & 64.7 & 44.2 \\
\hline China & 12 & 10.4 & 17.0 & 10.1 & 25.5 & 83.1 & 96.4 & 83.5 & 76.1 & 47.2 \\
\hline EC & 24 & 23.4 & 44.2 & 10.3 & 17.8 & 71.1 & 125.6 & 91.2 & 61.8 & 64.8 \\
\hline
\end{tabular}

Sources: WTO Secretariat, Trade profiles [website]. World Bank, Doing Business [website]. Notes: [a] GDP (in U.S. dollar, 2004) as a share of world GDP. [b] WTO Trade profiles. [c] Doing Business indicators (2007). [d] Counting as one the 10 countries having acceded to the EC in 2004. [e] Counting as one the EC.

Columns 2 and 3 give the GDP shares of the seven countries' trading partners in the world GDP calculated both at current and PPP exchange rates. Thus they offer a sense of the coverage of the market preferences that could be created by the size of the partners in the existing and future bilaterals of the seven countries in question. Multiplying the coverage indicator by indicators of the level of preferences offers the magnitude of the expected 
preferences. Columns 2 and 3 show the diversity of the situations. The current bilaterals cover a very low share of world GDP, except for the two smallest economies. But the bilaterals under negotiation or consideration dramatically changes the picture. The Commission's proposal generates such a change of scale in bilateralism that it could trigger a race to bilaterals among the large countries, if China and/or the U.S. feel compelled to follow a strategy as aggressive as the one designed in the EC proposal.

Columns 4 and 5 of Table 8 focus on tariffs, the first key instrument that could determine the level of preferences in trade in goods. ${ }^{18}$ A low average of applied tariffs suggest bilaterals more focused on market opening than on market preferences. By contrast, bilaterals behind a high average of applied tariffs are prone to market preferences. The same could be said in case of high average bound tariffs. Column 4 shows that the EC partners have the highest average applied tariffs of the bilaterals under negotiation or consideration by the Commission's proposal. Column 5 based on bound tariffs suggests again possible substantial market preferences for the bilaterals under negotiation or consideration by the four largest countries. In sum, the bilaterals involving the smaller economies tend to focus on market access, in sharp contrast to the EC bilaterals that are dominated by market preferences.

Columns 6 and 7 focus on non-tariff barriers, the other key instrument that could determine the level of preferences in trade in goods. As there is no direct measure of such barriers, Table 8 relies on the ranking of the partners of the seven countries in two respects: the ease of trading across borders and the ease of dealing with licences, two indicators estimated by the Doing Business database. Ranks are crude indicators. But the average ranks in columns 6 and 7 exhibit differences among of the seven countries' partners so large that they are likely to be meaningful. Once again, the bilaterals under negotiation or consideration by the EC appear the more prone to market preferences.

Column 8 to 10 look at services and investments, also with the help of indicators provided by the Doing Business database. The services dimension is captured by the global indicator of the ease of doing business with the various trading partners of the seven countries examined,

\footnotetext{
${ }^{18}$ This is why the seven countries are ranked by the increasing level of the average tariffs applied by their partners in bilaterals.
} 
whereas the investment dimension is indicated by the ranks in property registering and in investors protection among trading partners. These indicators show the EC and China on the one hand, and on the opposite side the five other countries. Once again, the bilaterals under negotiation or consideration by the EC appear the more dominated by market preferences.

To conclude, bilaterals under negotiation or consideration by the Commission's Global Europe agenda seem to be seriously biased towards substantial market preferences. Their short term political benefits for the EC may be quickly eliminated by their long terms economic costs generated by market preferences and their erosion following new bilaterals or multilateral trade negotiations. They may also create serious systemic risks in the world trade regime. In particular, they magnify the risk that the aggressive approach of the Commission might trigger a race to bilaterals, by inducing the U.S., China and Japan to "catch up" in terms of bilaterals.

\section{The Economic Partnership Agreements between the EC and the ACPs}

A series of bilaterals currently under negotiations by the EC deserves a special attention: the Economic Partnership Agreements (EPAs) with 75 African, Caribbean and Pacific countries (ACPs).

To some extent negotiating these EPAs was required by WTO rules. The Yaoundé (1963 and 1971) then Lomé (1975, 1981, 1985 and 1990) then Cotonou (2000) Conventions did not require reciprocity: the EC eliminated its tariffs on ACP products while the ACPs were allowed to keep their own tariffs on EC products. ${ }^{19}$ As a result, these Conventions were not fully consistent with the WTO non-reciprocity rule which is possible for least developed countries, but not for developing countries where reciprocity is the rule (roughly half of the ACPs are developing countries). This partial inconsistency was protected by a waiver that was due to expire by December 31, 2007. Despite the fact that the EC and the ACPs started their discussions on the post-waiver regime as soon as in 2000 , nothing happened before October 2007.

\footnotetext{
${ }^{19}$ It is worth noting that the non-reciprocity feature was to be a favor to the ACPs. In fact, it was quite costly for the ACPs, as underlined by Kreinin [1973].
} 
Then, suddenly, the Commission decided to launch negotiations on the new EPAs, and it pledged to conclude them by December 2007. The Commission argued that the waiver deadline had to be strictly enforced, an interpretation that was contested by many WTO experts. $^{20}$

EPAs require ACPs to eliminate tariffs on 80 percent of their tariff lines for products imported from Europe, so that the trade between the EC and each ACP would be tariff-free on 90 percent of the tariff-lines (the average of 100 percent on the EC side and 80 percent on the ACP side). It was the EC that defined this threshold of 90 percent, assuming that it would be high enough to meet a key provision of GATT Article XXIV ("substantially all the trade between the constituent territories" should be covered by a PTA). ACPs unwilling to sign EPAs have only one alternative. Least-developed ACPs (39 countries) could adopt the EC "Everything but Arms" initiative, if not yet done. Developing ACPs could turn to the Generalized System of Preferences, an alternative representing a serious reduction in the access of ACPs' producers to EC markets.

Will EPAs be costly to the ACPs [Delpeuch 2007]? The main reasons for a positive answer are captured by the following example. Nigeria's average bound tariffs are 150 percent in agriculture and 66 percent in manufacturing (NAMA). If the EC products enter the Nigerian markets duty-free, the EC firms could price their products at up to 1.5 and 0.6 times higher than the world price, respectively. The resulting distortions in ACP economies are huge. Behind such high tariffs, inefficient EC firms could charge high prices, and still be preferred to efficient exporters from the rest of the world which have to pay the high ACP tariffs. In such a case, the preferences granted by the ACPs in the EPAs are equivalent to ACP subsidies paid by the (very) poor ACP consumers to these inefficient EC firms. Meanwhile, behind such high tariffs, EC efficient firms could also charge high prices in order to grab the rents generated in the ACP markets by the high tariffs imposed by the ACPs on imports from non-EC sources. In sum, Nigerian consumers, including Nigerian firms which are often large

\footnotetext{
${ }^{20}$ Last but not least, the EPA issue was intertwined with a very controversial issue: the EC regime of banana imports. Since 1958, the EC regime was imposing all kinds of non-tariff barriers in an effort to discriminate in favor of ACPs bananas and against bananas from Latin America. It was only in December 2009 that a solution was finally accepted by all the parties: the ACPs, the Latin American producers, the U.S. and the EC.
} 
consumers, will hardly benefit from liberalization. At the same time, the Nigerian government will lose tariff revenues, and Nigerian firms will have hard time to enter their own markets once fully open to EC firms, loosing opportunities to diversify the Nigerian economy.

It could be said that this example provides too dark a picture of the situation because the effectively applied tariffs may be lower than bound tariffs. Table 9 suggests that this caveat should be treated with great caution. First, half of the ACPs have average applied tariffs higher than 15 percent in agriculture and one fourth have average tariffs higher than 15 percent in manufacturing.

Table 9. ACPs current bound and applied tariffs: an overview

\begin{tabular}{|c|c|c|c|c|c|c|c|c|c|}
\hline & \multicolumn{4}{|c|}{ Agriculture (farm and food) } & \multicolumn{4}{|c|}{ Manufacturing (NAMA) } & \multirow{4}{*}{$\begin{array}{c}\text { Overall } \\
\text { binding } \\
\text { coverage } \\
9\end{array}$} \\
\hline & \multicolumn{2}{|c|}{ bound tariffs } & \multicolumn{2}{|c|}{ applied tariffs } & \multicolumn{2}{|c|}{ bound tariffs } & \multicolumn{2}{|c|}{ applied tariffs } & \\
\hline & average & maximum & average & maximum & average & maximum & average & maximum & \\
\hline & 1 & 2 & 3 & 4 & 5 & 6 & 7 & 8 & \\
\hline Number of countries with available dat & 55 & 11 & 62 & 11 & 55 & 11 & 62 & 11 & 53 \\
\hline Average tariff or binding coverage & 78.1 & 85.9 & 17.1 & 48.4 & 46.2 & 75.9 & 12.0 & 40.0 & 64.3 \\
\hline \multicolumn{10}{|l|}{ Number of countries with: } \\
\hline bound tariff higher than $30 \%$ & 48 & 9 & - & - & 37 & 8 & - & - & 37 \\
\hline bound tariff higher than $50 \%$ & 37 & 9 & -- & - & 23 & 8 & - & - & 30 \\
\hline bound tariff higher than $70 \%$ & 33 & 7 & -- & - & 12 & 6 & - & -- & 28 \\
\hline applied tariff higher than $15 \%$ & -- & - & 33 & 11 & -- & -- & 15 & 11 & -- \\
\hline applied tariff higher than $20 \%$ & -- & -- & 18 & 8 & -- & -- & 3 & 9 & -- \\
\hline applied tariff higher than $30 \%$ & -- & -- & 2 & 4 & -- & -- & 1 & 4 & -- \\
\hline
\end{tabular}

Sources: WTO Member Information (WTO website) and Tariff Profiles when data are not available in Member Information files. Applied tariffs are for 2001. Author's calculations.

Second, Table 9 shows that the "peak" tariffs applied by the ACPs are very high: almost 50 percent on average for all the ACPs in agriculture, and 40 percent in manufacturing. These peak tariffs are concentrated in domestically produced products (a feature meaning that, politically, these are the tariffs the most likely to be kept unchanged under the EPAs by the ACPs since they are backed by large lobbies) and because they are the source of the largest welfare costs for the imposing country.

Last, many ACPs tariffs are still not bound. As a result, they can be increased without restraint, thus representing huge risks for foreign traders. For instance, half of the African ACPs have bound less than a third of their tariff lines. Indeed, the increase of imports from the EC following the implementation of the EPAs is likely to induce ACPs governments to raise their unbound tariffs on non-EC imports. This is economically unsound, yet a 
politically likely reaction from the ACPs.

As of May 2010, less than two third of the ACPs have initialled (19 ACPs) or signed (26 ACPs) EPAs. No EPA has been ratified. Moreover, a key initial goal of the EPAs, to favour regional integration among ACPs, had to be abandoned. All concluded EPAs are de facto or de jure bilateral, with the exception of the EPA which involve the 15 Caribbean ACPs.

Why such a slow, limited and uneven process? First is the fact that the aggressiveness with which the Commission undertook the negotiations under Commissioner Mandelson generated deep oppositions in the ACPs and serious concerns in many ECMS, such as Britain or France. Lady Ashton (the Trade Commissioner succeeding Lord Mandelson) did not fully remove these concerns despite her efforts to introduce some flexibility in the rigid format of the EPAs. The second reason is that the ACPs did not try to come up with better alternatives for themselves because most of their governments are still convinced that any additional trade liberalization would be detrimental to their growth and development. So, they ended up by trying to increase the number of products which could remain protected, making the EPAs even more costly to themselves.

Lastly, if the EPA's are costly for the ACPs, they may become a political trap for the EC. In the long run, they will be perceived by the ACPs as a way to provide a preferred access to EC firms to the detriment of the efficient firms from emerging economies, such as Brazil in agriculture or China in manufacturing. The political cost of what could be branded as neoimperialism could be enormous for the EC in the long run.

\section{Conclusion}

In 2010 the EC is facing a severe crisis, with several eurozone members in great difficulties or even on the verge of bankruptcy. As this crisis will not disappear quickly, it raises several important questions.

First is the EC capable of assuming again initiatives on the trade front in the coming months or years (from mid-2009 to mid-2010, the EC has been already relatively inert on the WTO 
front). An important way for the EC to show its dynamism would be to launch exploratory talks in services. This sector is not only large, but it is still plagued by huge transaction costs - two to three times those in goods [Miroudot, Sauvage and Shepherd 2010]. As the Doha Round is stuck with its self-inflicted constraint of the sequencing of the negotiations ("let us settle goods first") such exploratory talks on opening services should find another forum. There are several options, the most logical being the Transatlantic forum. If satisfactory, such talks would be very likely to trigger interests among the 10 or so largest trading partners of the U.S. and the EC. If successful in this wider context (the U.S., the EC and these ten large countries would represent more than 80 percent of the world value added in services) these talks could then be repatriated into the WTO forum, and contribute to unlocking the Doha negotiations.

Second, the EC should seriously review its use of trade policy as a foreign policy instrument. As suggested above, the short-term benefits of such an approach should be balanced against the long term costs which are almost unavoidable for the following reason: the logic of foreign policy is to sign as many bilaterals as possible. In trade terms, this logic implies that future bilaterals will erode the preferences created by today bilaterals - a sure way to make businesses disoriented and dillusioned.

Last, commercial policy is only one of the many policy instruments available to a government. "Over-using" such an instrument is a strong tendency in the EC because of the way the Treaty is designed, and because it allows the Commission to maximize its role. But, such an over-use may be a source of problems. A good illustration is the so-called the EC "energy dependency" with respect to Russia. What seems to be a trade problem (EC gas imports from Russia and Central Asian countries) is fundamentally a EC domestic problem, namely the absence of a competitive EC energy market. Improving competition in the EC energy markets would be one of the best ways to reduce the EC "dependency".

\section{References}

Amatori, F. 1999. European business : new strategies, old structures. Foreign Policy, Summer: pp78-89. 
Australian Productivity Commission (2009) 'Reform beyond the crisis'. Annual Report 2008-2009. Australian Government. http://www.pc.gov.au Canberra.

Bouët and Laborde (2009) 'The potential costs of a failed Doha Round', Discussion paper 886. IFPRI, Washington, DC.

Businesseurope (formerly UNICE) (2001) http://www.businesseurop.eu (search for the page on WTO).

Breuss, F. G. Fink and S. Griller, 2008. Services Liberalization in the Internal Market. Springer, Wien-New York.

Conway, P., V. Janod and G. Nicoletti, 2005. Product Market regulations in OECD countries: 1998 to 2003. Economic Department Working Papers. OECD, Paris.

Delpeuch, C. and G. Harb, 2007. EPAs: Thinking outside the European box. GEM Working paper. Downloadable from http://gem.sciences-po.fr

European Commission. 2006. Global Europe: Competing in the world. Communication, $\operatorname{COM}(2006) 567$.

Gros, D. 2007. EU services trade: where is the Single Market in services? 19 February. CEPS. Downloadable from http://www.ceps.eu.

Ilzkovitz F., A. Dierx, V. Kovacs and N. Sousa. 2007. Steps towards a deeper economic integration: the Internal Market in the $21^{\text {st }}$ century. A contribution to the Single Market Review. European Economy. No. 271. January.

Ilzkovitz F., A. Dierx, and N. Sousa. 2008. An analysis of the possible causes of product market malfunctioning in the EU: First results for manufacturing and services sectors. Economic papers 336. August. European Economy.

Kutas, G. 2010. Impact of the Doha Round on the European agricultural sector. PhD thesis. Sciences Po Paris.

Kreinin, M.E. 1973. Some Economic consequences of reverse preferences, March, Journal of Common Market Studies. Reprinted in M.E. Kreinin, 1974. Trade relations of he EEC. Chapter 4, pp.57-73. Praeger Publishers.

Messerlin, P. 2001. Measuring the Costs of Protection in Europe. European Commercial Policy in the 2000s. Peterson Institute for International Economics

Messerlin, P. 2007. Economic and Regulatory Reforms in Europe : Past Experiences and Future Challenges. The Sixth Snape Lecture. Productivity Commission, Australia http://www.pc.gov.au

Messerlin, P. 2008. The EC neighbourhood policy: an economic review. Journal of International Trade and Diplomacy. No.2, vol.2, pp.25-54. 
Messerlin, P. 2011. The Doha Round. In A. Lukauskas, R. M. Stern, and G. Zanini (eds.), Handbook of Trade Policy for Development, Oxford University Press, forthcoming.

Miroudot, S., J. Sauvage and B. Shepherd, 2010. Measuring the costs of international trade in services. May. GEM Working paper. http://gem.sciences-po.fr

Nicoletti, Giuseppe. 2000. Regulation in Services: OECD Patterns and Economic Implications. OECD Economics Department Working Paper (16 October). Paris: OECD.

OECD, 2006. OECD's FDI regulatory restrictiveness index: revision and extension to more economies. Working Papers on International investment. No. 2006/4.

Orden, D T. Josling and D. Blandford. 2010. WTO Disciplines on Agricultural Support:

Seeking a Fair Basis for Trade, forthcoming.

Annex I. The Treaties establishing the European Community and Union

\begin{tabular}{ccc}
\hline Dates & City of signature & Name of the Treaty \\
\hline 1951 & Paris & European Community of Steel and Coal (ECSC) \\
1957 & Rome & European Economic Community (EEC) \\
1957 & Rome & European Community of the Atomic Energy (Euratom) \\
1965 & Brussels & The Merger Treaty \\
1970 & Brussels & The Budgetary Treaty \\
1972 & Brussels & Acts of Accession (Denmark, Ireland and the United Kingdom) \\
1975 & Brussels & The Budgetary Treaty \\
1979 & Athens & Act of Accession (Greece) \\
1985 & Lisbon, Madrid & Acts of Accession (Portugal and Spain) \\
1986 & Luxembourg, The Hague & The Single European Act \\
1992 & Maastricht & The Treaty on European Union (TEU) \\
1994 & Corfu & Acts of Accession (Austria, Finland and Sweden) \\
1997 & Amsterdam & The Treaty of Amsterdam \\
2001 & Nice & The Treaty of Nice \\
2003 & Athens & Acts of Accession [a] \\
2004 & Rome & Acts of Accession [b] \\
2005 & Neumunster Abbey & The Treaty establishing a Constitution for Europe \\
2009 & Lisbon & Consolidated Version of the Treaty on the Functioning of the European Union \\
\hline
\end{tabular}

Sources: Official Journal. Notes: [a] Cyprus, Czech Republic, Estonia, Hungary, Latvia, Lithuania, Malta,

Poland, Slovakia, Slovenia. [b] Bulgaria, Romania. 